\section{Test ban to go comprehensive?}

SIR-The differing perceptions of Mexico and the United States prevented the production of a final document at the Nuclear Non-Proliferation Treaty (NPT) Review Conference in Geneva from 20 August to 14 September. But was Mexico's protest really "unrealistic" and "counterproductive"? ("NPT in serious trouble", Nature 347, 213; 1990)? Has it harmed the treaty to the extent that the principle of consensus needs to be broken, for example by making use of the amendment process? Has this meeting set a precedent for failure of the review and extension conferences of the treaty in 1995?

A crucial issue is whether pressures to amend the NPT will strengthen or destroy the treaty. It was agreed by all participants in the 1975 review conference (which itself nearly ended in deadlock) that every effort should be made to reach decisions by consensus. It was thought that any decision arrived at by simple majority (even near-unanimity) would be an imposition on those losing the vote and would lead to states leaving the NPT as permitted under article X. It would thus be a greater indication of failure than nonagreement on a final document.

On listening to the speeches in the plenum of the review conference, one fact becomes plain: everybody thinks the NPT is a valuable and important treaty that should be preserved. Everybody speaks of the necessity of its extension.

The question is: what measures are required to ensure extension for a meaningful period beyond 1995? The nonaligned states, including Mexico, answered that it was the conclusion of a Comprehensive Test Ban Treaty before 1995 .

Since 1981, neither the United States, the Soviet Union nor the United Kingdom has participated in such negotiations. Calls by more than a third of the parties to the Partial Test Ban Treaty to amend it to a comprehensive treaty or secure a mandate for the Conference on Disarmament ad hoc committee to negotiate a test ban show the degree of frustration felt by many states.

The United States will go to the amendment conference in New York on 7-18 January facing difficult if not insuperable diplomatic problems. Rumours are circulating that the United States may walk out after the first day. For the nonaligned, the problems of ensuring unity are just as important. At least one ambassador to the review conference from a prominent non-aligned country has expressed his anger at the Mexican delegation's stance.

A Partial Test Ban Treaty amended to a comprehensive treaty would halt the qualitative improvement of nuclear weapons and would do much to safeguard the future of the Nuclear Non-Proliferation Treaty.

DAVID LOWRY
PAUL HELLIWELL
European Proliferation Information
Centre,
258 Pentonville Road,
London N1 9JY, UK

\section{Problems of UK universities}

SIR-There is no doubt that British universities could and should do more to recover a greater fraction of overheads from external research contracts than the 14 per cent reported by Science and Engineering Policy Studies Unit (SEPSU) (Nature 347, 506; 1990). Something like the old University Grants Committee estimate of 40 per cent would certainly make our university finance officers happier, but according to SEPSU even this is far too low. In strict accountancy terms, I do not doubt that SEPSU can justify this, but how do they allow for the hidden benefit (overhead) that accompanies most external funding to universities?

Many 'soft-money' university researchers usually find time within their contract to pursue aspects of related, non-contract research which enhances their academic progress, and that of their department and discipline. Furthermore, many take an active role in undergraduate and postgraduate education and training. Without their input, the staff funded by the Universities Funding Council (UFC) would find it even more difficult to cope with their academic duties in the face of declining support from government.

It would seem that any estimate of research overheads should allow for this, by deducting what it would cost the universities to provide UFC-funded staff to take over the voluntary academic duties of our soft-money colleagues. MichaEL J. STOCK

Department of Physiology,

St George's Hospital Medical School, London SW17 ORE, UK

SIR - Your leading article on undergraduate university funding in the United Kingdom (Nature 345, 462; 1990) and the current changes proposed in the school syllabus prompts me to raise two fundamental issues.

First, will the accepted decline of the factual scientific knowledge of the school-leaver affect the length, content and standard of degree courses? The answer must be yes, particularly where the acquisition of a basic "data base' is paramount, for example basic medical science and the natural sciences. In turn, this can only increase the length of $\mathrm{PhD}$ registration.

The second issue is more sinister. It has been suggested that the measure of success in school can be measured from the percentage of higher grades awarded. It does not require a quantum leap of the imagination to see that university funding may also depend on such perceived success - the number of firsts awarded. The result may well be an erosion of standards that will adversely affect the academic competitiveness of the United Kingdom. ANJAN BANERJEE

Department of Clinical Biochemistry,

King's College Hospital,

Denmark Hill, London SE5 9PJ, UK

\section{The testing of laetrile}

SiR-John Cairns (Nature 345, 585; 1990), in reviewing Ralph Moss's book The Cancer Industry, says that Moss thought that the Sloan Kettering Center (SKC) "trials of laetrile had been rigged to give a negative result. This explains the theme in most of the chapters which is that... probably some wondrous cure for cancer is being suppressed by the chemical industry and the cancer establishment After all if something like laetrile really worked . . . it is hardly conceivable that the many people who have been given laetrile would keep silent

Laetrile is a poor example for Moss's thesis. Laetrile (amygdalin) is a cyanogenic glycoside that was proposed for cancer treatment on the basis that it would be broken down by an enzyme in cancerous tissue to liberate cyanide which would "kill the cancer". This hypothesis was falsified by D. M. Greenberg's experiments', after which the proponents of laetrile alleged, without any evidence, that it was "vitamin $\mathrm{B}_{17}$ ", a deficiency of which caused cancer ${ }^{2}$. This fantasy was used to promote laetrile for cancer, and political pressure was exerted on the National Cancer Institute to schedule tests at four prominent cancer centres including SKC and Mayo Clinic. Not one patient was cured or even stabilized. The trials were not "rigged". Indeed, it is hard to conceive of a test of laetrile being "rigged", except by omitting the medication. The "many people who have been given laetrile" did not all "keep silent". Some of them or their surviving relatives have participated in various court cases in which punitive action was brought against the dispensers of laetrile ${ }^{3}$

THOMAS H. JUKES

University of California,

Berkeley, California 94720, USA

1. Greenberg, D. M. Western J. Med. 122, 345-348 (1975).

2. Jukes, T. H. Nature 269, 283 (1977)

3. Yarbro, J. W. Missouri Medicine 76, 195-206 (1979) 